\title{
Effect of Feeding Enriched Formulated Diet and Live Feed on Growth, Survival and Fatty Acid Profile of Deccan Mahseer, Tor Khudree (Sykes) First Feeding
} Fry

\author{
Soibam Khogen Singh ${ }^{1 *}$, Upasana Mishra ${ }^{1}$, Sibnarayan Dam Roy ${ }^{1}$, Chadha NK ${ }^{1}$ and Venkateshwarlu G² \\ ${ }^{1}$ Aquaculture Division, Central Institute of Fisheries Education, Mumbai - 400061, India \\ ${ }^{2}$ Fish Processing Technology Division, Central Institute of Fisheries Education, Mumbai-400061, India
}

\begin{abstract}
Deccan mahseer (Tor khudree) has recently been included in the IUCN list of threatened species due to its declining population. Intervention of nutritional strategies for better growth and survival of early stages for grow out and ranching is essential. The present investigation intended to study the effect of various dietary combinations containing live and inert feed enriched with cod liver oil on growth and survival of Tor khudree first feeding fry, while effects on whole body fatty acid composition of fry were also studied. Cod liver oil as a source of essential fatty acids was used for enriching both live and inert formulated feed. The experimental design consist of four treatments viz. T0 (inert diet without enrichment), T1 (inert diet enriched with cod liver oil), T2 (inert diet enriched with cod liver oil+unenriched Artemia) and T3 (unenriched inert diet+enriched Artemia) fed to four distinct experimental groups for a period of 60 days. At the end of the experiment growth, survival and fatty acid profile of the fry were examined. Fry fed combination of unenriched inert diet and enriched Artemia (T3) had the highest growth and feed efficiency in terms of percentage weight gain (PWG), specific growth rate (SGR), average daily growth (ADG) and feed conversion ratio (FCR). Survival percentage was also significant in T3 compared to other groups. Enrichment of dietary components had a direct effect on the whole body fatty acid profile of mahseer fry with significant $(P<0.05)$ changes in the eicosapentaenoic acid (EPA 20:5 n-3) and docosahexaenoic acid (DHA 22:6 n-3) composition. This study provides avenues for improving the growth and survival of mahseer fry through enrichment and concurrent co-feeding strategies with dietary formulated diet which can further reduce feed cost during fry rearing
\end{abstract}

Keywords: Tor khudree; Enrichment; Co-feeding; EPA; DHA; First feeding fry; Cod liver oil; Enrichment

\section{Abbrevations}

IUCN (International Union for Conservation of Nature); PWG (Percentage weight gain); SGR (Specific Growth Rate); ADG (Average Daily Growth); FCR (Feed Conversion Ratio); EPA (Eicosapentaenoic Acid); DHA (Docosahexaenoic Acid)

\section{Introduction}

Mahseers are considered as potential candidate species for aquaculture, especially in the wake of the recent push toward the culture of indigenous species. Deccan Mahseer (Tor khudree) is one of the important coldwater fish species having market demand as a food fish and for recreational fisheries in India [1]. Recently the fish is paid special attention due to its rapid disappearance from natural environment and also ecological alterations and physical changes in natural environment [2]. The latest version of the IUCN Red List of Threatened Species has listed Tor khudree for the first time in the year 2007 as endangered because of a $60-70 \%$ decline in the native wild population during the past three generations (20 years), as a result of exploitation and habitat degradation. Commercial expansion of this species for aquaculture and stock enhancement in the natural waters requires special attention. The main bottleneck in the process is the limitation of optimum sized fingerlings for grow out or ranching into the natural waters. For promotion of mahseer, one alternative could be the development of suitable breeding and rearing technology which requires knowledge of their nutritional requirement from hatchlings to adult stage. Weaning success from live food to formulated feed remains a very critical period in which there is a gradual change from live prey to formulated [3]. Use of live food (Artemia metanauplii) during early developmental stages of $T$. khudree is expensive; therefore weaning in co-feeding with Artemia nauplii provides alternative weaning strategy for ensuring lower feed cost [4]. An overlapping co-feeding period during which live food is gradually replaced by increasing quantities of formulated feed has been shown to improve growth and survival of fish larvae compared to the use of live food only [5]. Moreover, formulated diets can balance the nutritional composition of live food especially with respect to amino acids which are not easy to modify in live food [6]. Live food may influence ingestion, digestion and assimilation of formulated diets [7] and also influences digestion by stimulating endocrine responses [8].

Essential fatty acids are unsaturated fatty acids that must be provided preformed in the diet [9]. The active forms in $n-3$ family are eicosapentaenoic acid (EPA 20:5 n-3) and docosahexaenoic acid (DHA 22:6 n-3). In general, warm water fishes require polyunsaturated n- 6 fatty acids or a mixture of n-3 and n- 6 fatty acids, while cold water species require n-3 forms [10]. Coldwater fishes have a higher requirement for n-3 PUFAs, whereas warm water fishes tend to have a greater requirement for $n-6$ fatty acids [11]. This is because; $n-3$ structure permits a greater degree of unsaturation, which is necessary

*Corresponding author: Soibam Khogen Singh, Aquaculture Division, Central Institute of Fisheries Education, Mumbai-400061, India, Phone: +918730854370; Fax: +913812865291; E-mail: gengang@gmail.com

Received June 17, 2012; Accepted July 24, 2012; Published July 30, 2012

Citation: Singh SK, Mishra U, Roy SD, Chadha NK, Venkateshwarlu G (2012) Effect of Feeding Enriched Formulated Diet and Live Feed on Growth, Survival and Fatty Acid Profile of Deccan Mahseer, Tor Khudree (Sykes) First Feeding Fry. J Aquacult Res Dev 3:143 doi:10.4172/2155-9546.1000143

Copyright: ( 2012 Singh SK, et al. This is an open-access article distributed unde the terms of the Creative Commons Attribution License, which permits unrestricted use, distribution, and reproduction in any medium, provided the original author and source are credited. 
Citation: Singh SK, Mishra U, Roy SD, Chadha NK, Venkateshwarlu G (2012) Effect of Feeding Enriched Formulated Diet and Live Feed on Growth, Survival and Fatty Acid Profile of Deccan Mahseer, Tor Khudree (Sykes) First Feeding Fry. J Aquacult Res Dev 3:143 doi:10.4172/21559546.1000143

Page 2 of 6

in the membrane phospholipids to maintain flexibility and permeability characteristics at low temperatures [12]. During fry rearing, live feed are the main food during live prey feeding. However, it is very difficult to reach optimal enrichment levels as ingested EPA/DHA is catabolised and used as an energy source by Artemia $[9,13,14]$. Therefore, the supplementation of formulated diets could be a solution to satisfy the nutritional requirements. During such transitional period, enriched live food is partially replaced by artificial diets until the fry can be fed solely on formulated diets. Early co-feeding is beneficial, since it reduces the use of live food, which are cumbersome to produce and difficult to manipulate nutritionally [15]. In addition, co-feeding is expected to improve the nutritional condition of the larvae and might facilitate earlier transition into dry feeds; only [16] of early co-feeding has been widely documented in various species such as tongue sole, Cynoglosssus semilaevis [17], barramundi, L. calcarifer [18], turbot, Scophthalmus maximus [19], and winter flounder, Pseudopleuronectes americanus [20].

While knowledge of the exact nutrient requirements of T. khudree is limited, lipids and essential fatty acids are generally recognised to play critical roles in larval development. Recent advances have led to the possible replacement of live feed organisms with micro diets from first feeding in Haddock, Melanogrammus aeglefinus [21]. Artemia metanauplii as starter diet may be too small and might not contain enough nutrients for the larval development. It has been established that high levels of (n-3) HUFA in the live feed can improve growth and survival of fish larvae in a number of species. Starting an early cofeeding with appropriate enriched diets, formulated diets or Artemia biomass can be a solution to improve and balance the larval nutrition and to shorten the live prey feeding period. Meanwhile, the appropriate nutritional composition, especially fatty acid contents of the formulated diets for co-feeding will be crucial for development of mahseer fry. The present work was intended to compare the effect of different dietary formulation combining both live feed and inert diet after enrichment using EPA/DHA sources on growth, survival and fatty acid profile of $T$. khudree first feeding fry.

\section{Materials and Methods}

\section{Maintenance of experimental fishes}

First feeding fry of T. khudree (Average weight: $0.10 \pm 0.12 \mathrm{~g}$ ) were procured from Tata Power Company Ltd. (TPCL), Lonavla, Maharashtra, India during October month and maintained at the rearing unit of Aquaculture Division, Central Institute of Fisheries Education, Mumbai, India. Fry were maintained with optimum conditions for another 20 days and fed on live feed. Round the clock aeration was provided to maintain an optimum dissolved oxygen. The entire tank bottom was siphoned clean every third day. The water quality parameters were checked once in three days and were found within the optimum range (dissolved oxygen: 7.0-7.2 $\mathrm{mg} \mathrm{L}^{-1}$; $\mathrm{pH}$ : 7.57.8; temperature: $20.4-24.8^{\circ} \mathrm{C}$; ammonia nitrogen: $0.14-0.23 \mathrm{mg} \mathrm{L}^{-1}$; nitrite nitrogen: 0.001-0.005 $\mathrm{mg} \mathrm{L}^{-1}$; nitrate nitrogen: 0.02-0.07 $\mathrm{mg} \mathrm{L}^{-1}$ ) throughout the experimental period as observed earlier by Sangma and Basavaraj [22].

\section{Experimental design and trial}

The experimental design consist of four treatments viz. T0 (inert diet without enrichment), T1 (inert diet enriched with cod liver oil), T2 (inert diet enriched with cod liver oil+unenriched Artemia) and T3 (unenriched inert diet+ enriched Artemia) with three replicates each following a completely randomized design (CRD). The experimental trial was conducted for a period of 60 days at the Aquaculture facility of the Institute. Plastic tubs of $70 \mathrm{~L}$ capacity covered with perforated lids were used for the trial. The tubs were filled with $50 \mathrm{~L}$ of chlorine free water and round the clock aeration was provided in all tanks. A total of 240 uniformly sized fry having an average weight of $0.40 \mathrm{~g} \mathrm{(20}$ fry $\times 4$ treatments $\times 3$ replicates) were uniformly distributed into the experimental groups and acclimatised for two days prior to the start of the experiment. Each diet (inert diet and live feed) was fed twice daily (09:00 and 17:00 hour) to triplicate group of T. khudree fry at 5\% of the body weight. Siphoning of the uneaten feed was carried out daily.

\section{Hatching and separation of Artemia nauplii}

Artemia cyst used in the study was supplied from Supreme Plus ${ }^{\mathrm{Tn}}$, Ogden, USA. Hatching of Artemia cysts were carried out as suggested by Sorgeloos et al. [23]. Prior to hatching, cysts were washed in active bleach liquor for six minutes followed by rinsing in chlorine free water. The cysts were incubated in a glass jar at density of $0.3 \mathrm{~g} 500 \mathrm{~mL}^{-1}$ for $24 \mathrm{~h}$ using saline water ( $25 \mathrm{ppt})$. Temperature of water during hatching of Artemia nauplii was maintained at $26^{\circ} \mathrm{C}$ and vigorous aeration was provided throughout the hatching period for efficient hatching of Artemia cyst into nauplii. After hatching, the nauplii were separated from the cyst using a rubber tube and a piece of blotting cloth and were washed for five minutes in clean chlorine free running water. The nauplii were then transferred to fresh saline water (12 ppt).

\section{Enrichment of Artemia nauplii}

The hatched nauplii were collected together in a tank containing saline water (12 ppt) and the enrichment emulsion was added at the rate of $0.5 \mathrm{~mL} \mathrm{~L}^{-1}$ of the Artemia nauplii containing water with a density of 100-150 nauplii $\mathrm{ml}^{-1}$. The enrichment was conducted for $12 \mathrm{~h}$. The Artemia nauplii containing water was provided with vigorous aeration to ensure thorough mixing. The composition of the emulsion used for enriching the Artemia is given in Table 1.

\section{Formulation of inert diet}

A purified inert diet containing $45 \%$ protein was formulated using ingredients obtained from Himedia Laboratories, Mumbai, India. Composition of diet and their proximate analysis are presented in Table 2. The required amount of the ingredients were weighed and mixed properly. Cod liver oil as a source of EPA/DHA was added gradually to assure the homogeneity of the ingredients. The mixed ingredients were passed through a single screw pelletizer with $1 \mathrm{~mm}$ dia.

\section{Growth and survival}

Fry in each tub were bulk weighed every week to monitor the growth rates. The growth performance of the fingerlings was evaluated in terms of percentage weight gain, specific growth rate (SGR), feed efficiency ratio (FER), feed conversion ratio (FCR), feed conversion efficiency (FCE), average daily growth (ADG) based on the following standard formulae:

Weight gain $\%=($ final weight-initial weight $) /($ initial weight $) \times 100$

\begin{tabular}{|l|l|}
\hline Ingredients & Composition \\
\hline Water & $100 \mathrm{ml}$ \\
\hline Cod liver oil & $20 \mathrm{ml}$ \\
\hline Egg yolk & $11 \mathrm{ml}$ \\
\hline Gelatine & $3.7 \mathrm{~g}$ \\
\hline Vitamin E & $40 \mathrm{mg}$ \\
\hline
\end{tabular}

Table 1: Composition of emulsion used for enrichment. 
Citation: Singh SK, Mishra U, Roy SD, Chadha NK, Venkateshwarlu G (2012) Effect of Feeding Enriched Formulated Diet and Live Feed on Growth, Survival and Fatty Acid Profile of Deccan Mahseer, Tor Khudree (Sykes) First Feeding Fry. J Aquacult Res Dev 3:143 doi:10.4172/21559546.1000143

Page 3 of 6

\begin{tabular}{|l|l|l|}
\hline \multicolumn{2}{|l|}{ Enriched Diet } & Unenriched Diet \\
\hline Ingredients & 37.78 & 37.78 \\
\hline${ }^{*}$ Casein & 10.00 & 10.00 \\
\hline${ }^{*}$ Gelatin & 5.00 & - \\
\hline ॠCod liver oil & - & 5.00 \\
\hline ॠSunflower oil & 2.00 & 2.00 \\
\hline Vitamin' & 4.00 & 4.00 \\
\hline Mineral ${ }^{2}$ & 1.00 & 1.00 \\
\hline${ }^{*}$ Carboxy Methyl Cellulose & 25.22 & 25.22 \\
\hline${ }^{*}$ Dextrin & 10.00 & 10.00 \\
\hline${ }^{*}$ a-cellulose & & \\
\hline Proximate composition & $93.94 \pm 0.87$ & $92.97 \pm 0.13$ \\
\hline Dry matter & $45.92 \pm 0.27$ & $45.06 \pm 0.35$ \\
\hline Crude protein & $9.96 \pm 0.05$ & $9.47 \pm 0.08$ \\
\hline Lipid & $4.60 \pm 0.01$ & $4.68 \pm 0.02$ \\
\hline Ash & $8.21 \pm 0.08$ & $8.12 \pm 0.03$ \\
\hline Crude fibre & &
\end{tabular}

${ }^{1}$ Mineral premix (\%): $\mathrm{KAl}\left(\mathrm{SO}_{4}\right), 0.159 ; \mathrm{CaCO}_{3}, 18.101 ; \mathrm{MgSO}_{4}, 5.216 ; \mathrm{CoCl}_{2}, 0.07$ $\mathrm{KCl}, 16.553$; ferric citrate $\left(5 \mathrm{H}_{2} \mathrm{O}\right), 1.338$; sodium selenite, $0.004 ; \mathrm{MnSO}_{4} \cdot \mathrm{H}_{2} \mathrm{O}, 0.07$; $\mathrm{KI}, 0.014 ; \mathrm{ZnSO}_{4}, 0.192 ; \mathrm{NaH}_{2} \mathrm{PO}_{4}, 13.605 ; \mathrm{CuSO}_{4} .5 \mathrm{H}_{2} \mathrm{O}, 0.075$

${ }^{2}$ Vitamin premix: thiamine hydrochloride, $10 \mathrm{mg} \mathrm{kg}^{-1}$; riboflavin, $20 \mathrm{mg} \mathrm{kg}^{-1}$; calcium pantothenate, $40 \mathrm{mg} \mathrm{kg}^{-1}$; nicotinic acid, $50 \mathrm{mg} \mathrm{kg}^{-1}$; pyridoxine hydrochloride, 10 $\mathrm{mg} \mathrm{kg}^{-1}$; folic acid, $5 \mathrm{mg} \mathrm{kg}^{-1}$; inositol, $400 \mathrm{mg} \mathrm{kg}^{-1}$; choline chloride, $2000 \mathrm{mg} \mathrm{kg}^{-1}$; menadione, $10 \mathrm{mg} \mathrm{kg}^{-1}$; cholecalciferol, $1500 \mathrm{IU}$; biotin, $1 \mathrm{mg} \mathrm{kg}^{-1}$; vitamin B12, 0.02 $\mathrm{mg} \mathrm{kg}^{-1}$; vitamin A, $3000 \mathrm{IU}$; vitamin E, $50 \mathrm{IU}$; vitamin C, $200 \mathrm{mg} \mathrm{kg}^{-1}$

II Procured from local market

*Himedia Laboratories, Mumbai, India

Data are expressed as mean $\pm \mathrm{SE}$

Table 2: Formulation of experimental inert diet $(\mathrm{g} / 100 \mathrm{~g})$ for $T$. khudree fry and proximate composition (\% dry weight).

SGR $=100$ (ln average final weight-ln average initial weight) $/$ number of culture days

$\mathrm{FCR}=$ total dry feed intake $(\mathrm{g}) /$ live weight gain $(\mathrm{g})$

$\mathrm{ADG}=($ mean final weight - mean initial weight $) /$ days of culture

Survival $(\%)=($ total number of animals harvested/total number of animals stocked)X100

\section{Biochemical analysis}

The biochemical compositions of formulated diet, emulsion, Artemia nauplii and T. khudree fry were measured using standard methods [23] for moisture, ash, crude protein, lipid and crude fibre.

\section{Fatty acid analysis}

Total lipid was extracted using Folch method [24] with some modification from the enriched and unenriched Artemia nauplii, formulated feed and the larval tissue. The AOAC [25] method was followed to esterify the lipid extract. Fatty acid methyl esters (FAME) was prepared from the extracted lipids by heating with methanolic $\mathrm{NaOH}$ and then with $\mathrm{BF}_{3}$ Methanol for esterification. N-heptane (5 $\mathrm{mL}$ ) was added to recover the methyl esters in organic phase. Saturated $\mathrm{NaCl}$ solution was added to the mixture and the aqueous and organic layers were separated using a separating funnel. The upper N- heptane phase was pipetted out and stored in $10 \mathrm{~mL}$ glass vials in refrigerator until further analysis. Gas chromatography-Mass spectrometry (GCMS) measurements were performed using a Shimadzu QP2010 quadrupole Gas Chromatography Mass Spectrometer equipped with a carbowax (30 m×0.25 mm ID; $0.25 \mu \mathrm{m}$ film thickness) capillary column (Cromlab S.A). Helium was used as the carrier gas. Injector and detector temperatures were set at $250^{\circ} \mathrm{C}$. Injection was performed in split mode (1:15). The column temperature was programmed initially at

$50^{\circ} \mathrm{C}$ for $2 \mathrm{~min}$ and then to increase at a rate of $10^{\circ} \mathrm{C}$ per min to a final temperature of $230^{\circ} \mathrm{C}$. FAM esters were separated at constant pressure $(23.1 \mathrm{kPa})$ and peaks were identified by comparing the mass spectra with the mass spectral data base.

\section{Principal component analysis (PCA)}

Principal component analysis (PCA) of samples fed with different experimental diets was performed by using Unscrambler (Version 9.5, CAMO, Norway).

\section{Statistical analysis}

All the data were analysed using SPSS version 16.0 for windows. One-way analysis of variance (One-way ANOVA) was used to compare all the treatments. Significant difference between two means was measured by Duncan's multiple range test. All the differences were considered significant at $P<0.05$ and the results are presented as mean \pm standard error (SE).

\section{Results}

\section{Growth and survival}

Effect of dietary treatment on important growth parameters viz. PWG, SGR, ADG and FCR are given in Table 4. Groups fed with enriched Artemia and unenriched inert diet (T3) recorded highest percentage weight gain $(297.00 \pm 0.42)$ which was significant $(P<0.05)$ whereas groups fed with unenriched inert diet (T0) exhibited lowest value (137.2 \pm 0.20$)$. SGR and ADG was highest in T3 $(2.28 \pm 0.00$; $22.21 \pm 0.00)$ and lowest in T0 $(1.45 \pm 0.00 ; 9.55 \pm 0.00)$ which was significant $(P<0.05)$. FCR followed a similar pattern which was

\begin{tabular}{|c|c|c|c|c|}
\hline \multirow[t]{2}{*}{ Fatty acids } & \multicolumn{2}{|c|}{ Before enrichment } & \multicolumn{2}{|c|}{ After enrichment } \\
\hline & ${ }^{1}$ Inert diet & Artemia & ${ }^{2}$ Inert diet & Artemia \\
\hline $12: 0$ & 0.70 & 0.28 & 0.33 & 0.20 \\
\hline 13:0 & ND & 0.24 & ND & 0.07 \\
\hline $14: 0$ & 3.30 & 1.78 & 5.77 & 5.40 \\
\hline 15:0 & 0.33 & 0.90 & 0.54 & 0.82 \\
\hline 16:0 & 18.4 & 14.48 & 19.27 & 19.13 \\
\hline $16: 1 \mathrm{n}-9$ & 0.03 & 6.34 & 4.06 & 7.48 \\
\hline $16: 1 \mathrm{n}-7$ & 0.63 & ND & 0.55 & 0.86 \\
\hline $17: 0$ & 0.21 & 1.50 & 0.34 & 0.72 \\
\hline 18:0 & 5.26 & 0.62 & 3.98 & 0.27 \\
\hline $18: 1 \mathrm{n}-9$ & 24.70 & 24.29 & 31.92 & 25.00 \\
\hline $18: 1 \mathrm{n}-7$ & 0.13 & 3.31 & 3.16 & 3.75 \\
\hline $18: 1 n-5$ & 9.73 & ND & 11.02 & 0.61 \\
\hline $18: 2 n-6$ & 0.10 & 8.90 & 3.08 & 8.50 \\
\hline 19:0 & 0.56 & ND & 0.25 & 0.16 \\
\hline $18: 3 n-3$ & 0.66 & 4.73 & 3.73 & 11.74 \\
\hline $20: 0$ & ND & 0.54 & 0.11 & 0.55 \\
\hline $20: 1 \mathrm{n}-9$ & ND & 0.65 & 0.77 & 6.04 \\
\hline $20: 2 n-6$ & ND & 1.01 & 0.13 & 1.03 \\
\hline $20: 3 n-3$ & ND & 0.89 & 1.36 & 1.29 \\
\hline $20: 4$ n-6 & ND & 1.30 & 0.32 & 1.40 \\
\hline $20: 4 n-3$ & ND & 1.40 & 0.72 & 1.49 \\
\hline $20: 5 n-3$ & 0.12 & 2.45 & 3.45 & 4.53 \\
\hline $22: 1$ n-9 & 0.12 & 0.53 & 1.75 & 1.83 \\
\hline $22: 6 n-3$ & 0.10 & 1.30 & 3.39 & 4.14 \\
\hline
\end{tabular}

${ }^{1}$ Inert diet with sunflower oil as lipid source represents unenriched diet

${ }^{2}$ Inert diet with cod liver oil as lipid source represents enriched diet *ND: Not detected

Table 3: Fatty acid profile (area \%) of enriched and unenriched Artemia nauplii and inert diet. 
Citation: Singh SK, Mishra U, Roy SD, Chadha NK, Venkateshwarlu G (2012) Effect of Feeding Enriched Formulated Diet and Live Feed on Growth, Survival and Fatty Acid Profile of Deccan Mahseer, Tor Khudree (Sykes) First Feeding Fry. J Aquacult Res Dev 3:143 doi:10.4172/21559546.1000143

\begin{tabular}{|l|l|l|l|l|}
\hline Treatments & PWG & SGR & ADG & FCR \\
\hline T0 & $137.20 \pm 0.20^{\mathrm{a}}$ & $1.45 \pm 0.005^{\mathrm{a}}$ & $9.55 \pm 0.003^{\mathrm{a}}$ & $2.71 \pm 0.003^{\mathrm{a}}$ \\
\hline T1 & $177.41 \pm 0.25^{\mathrm{b}}$ & $1.73 \pm 0.003^{\mathrm{b}}$ & $12.05 \pm 0.030^{\mathrm{b}}$ & $1.95 \pm 0.003^{\mathrm{b}}$ \\
\hline T2 & $196.45 \pm 0.26^{\mathrm{c}}$ & $1.80 \pm 0.003^{\mathrm{c}}$ & $16.13 \pm 0.003^{\mathrm{c}}$ & $1.95 \pm 0.003^{\mathrm{c}}$ \\
\hline T3 & $297.02 \pm 0.42^{\mathrm{d}}$ & $2.28 \pm 0.003^{\mathrm{d}}$ & $22.21 \pm 0.003^{\mathrm{d}}$ & $1.61 \pm 0.003^{\mathrm{d}}$ \\
\hline
\end{tabular}

PWG: Percentage weight gain; SGR: Specific Growth Rate; ADG: Average daily growth (mg/day); FCR: Feed Conversion Ratio; FER: Feed Efficiency ratio FCE: Feed conversion Efficiency; Mean values in the same column with different superscript $(a, b, c, d)$ differ significantly $(P<0.05)$. Data expressed as Mean \pm SE, $n=3$

Table 4: Growth parameters of $T$. khudree fry fed different experimental diets for 60 days.

\begin{tabular}{|l|l|l|l|l|l|}
\hline $\begin{array}{l}\text { Treat- } \\
\text { ments }\end{array}$ & Moisture & Crude Protein & Lipid & Ash & TC* \\
\hline T0 & $72.20 \pm 0.01$ & $15.80 \pm 0.02$ & $2.78^{\mathrm{a}} \pm 0.02$ & $4.60 \pm 0.03$ & $4.62 \pm 0.01$ \\
\hline T1 & $72.45 \pm 0.03$ & $15.50 \pm 0.02$ & $4.27^{\mathrm{b}} \pm 0.03$ & $3.50 \pm 0.03$ & $5.28 \pm 0.02$ \\
\hline T2 & $71.76 \pm 0.02$ & $15.02 \pm 0.01$ & $5.05^{\mathrm{b}} \pm 0.01$ & $3.40 \pm 0.02$ & $4.77 \pm 0.01$ \\
\hline T3 & $70.63 \pm 0.03$ & $16.70 \pm 0.03$ & $6.27^{\mathrm{c}} \pm 0.01$ & $3.02 \pm 0.01$ & $3.38 \pm 0.03$ \\
\hline
\end{tabular}

*TC- Total Carbohydrate

Mean values in the same column with different superscript (a, b, c, d) differ significantly $(\mathrm{P}<0.05)$. Data expressed as Mean $\pm \mathrm{SE}, \mathrm{n}=3$

Table 5: Proximate composition of Tor khudree (\% wet weight) fry after 60 days experimental feeding.

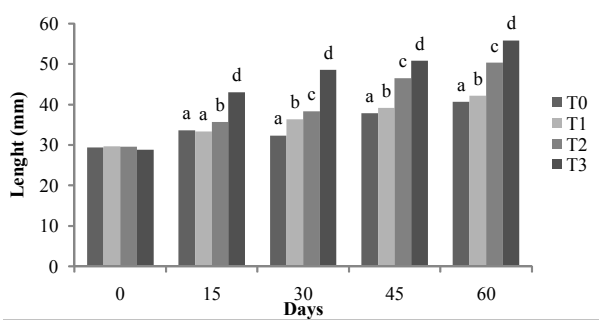

Figure 1: Growth of T. khudree fry measured as total length $(\mathrm{mm})$ measured at different sampling times during the experimental trial at $5 \%$ significance level.

significant $(P<0.05)$ among the groups. Rearing of T. khudree fry fed with different diets showed significant variation in survival (Figure $3)$. Percent survival did not show any variation up to 15 days but was significant $(P<0.05)$ after 15 days of experimental feeding. At the end of the trial, significant variation $(P<0.05)$ in survival was observed with better survival in $\mathrm{T} 3$ followed by $\mathrm{T} 2, \mathrm{~T} 1$ and $\mathrm{T} 0$.

\section{Fry whole body biochemical composition}

Proximate composition of $T$. khudree fry after 60 days experimental feeding is presented in Table 5. No significant variation in whole body composition was observed due to different experimental diets $(P>0.05)$ except lipid content which was significantly different among experimental groups $(P<0.05)$. Higher lipid content was observed in T2 and T3 (5.05 \pm 0.01 and $6.27 \pm 0.01$ respectively) which was significant $(P<0.05)$ from other groups. Whole body moisture content varied from $70.63 \pm 0.03$ to $72.45 \pm 0.03$ with highest in T1 and lowest in T3. Lowest crude protein was observed in T2 $(15.02 \pm 0.01)$ whereas highest in T3 $(16.70 \pm 0.03)$. Total carbohydrate was highest in T1 $(5.28 \pm 0.02)$ and lowest in T3 $(3.38 \pm 0.03)$. T0 exhibited highest ash content and T2 had lowest value.

\section{Fatty acid profile of Artemia/inert diet after enrichment}

The fatty acid profile of the Artemia nauplii and inert diet before and after enrichment is summarized in Table 3. In the inert diet no

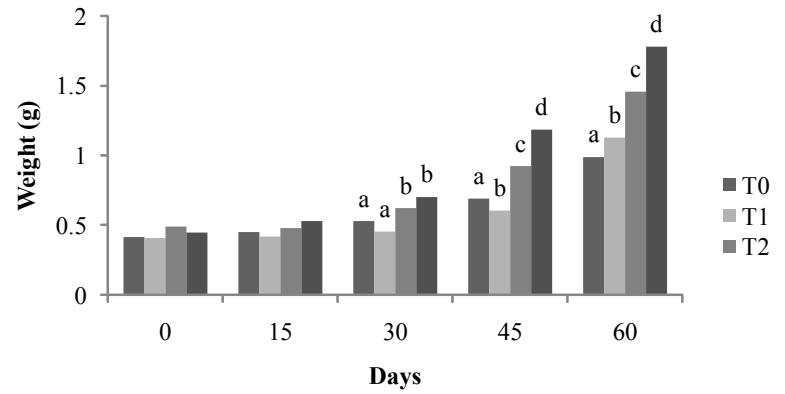

Figure 2: Growth of $T$. khudree fry measured as weight $(\mathrm{g})$ measured at different sampling times during the experimental trial at $5 \%$ significance level.

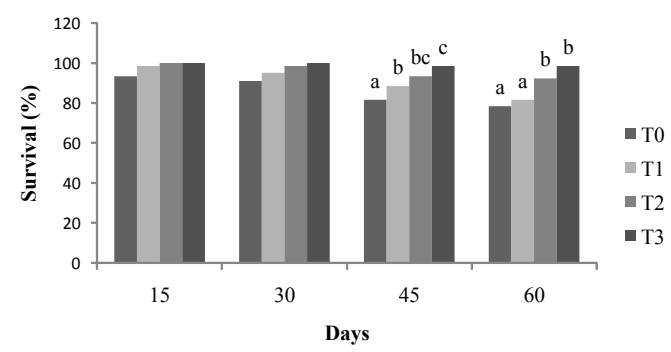

Figure 3: Survival rate (\%) of T. khudree fry in the different experimental groups at 15 days interval during the 60 days experimental trial at $5 \%$ significance level.

considerable changes in composition of short chain fatty acids (12:0, 14:0, 15:0, 16:0, 17:0 and 18:0) occurred due to dietary enrichment with cod liver oil. Monounsaturated fatty acids (MUFA) content in inert diet increased slightly. The Polyunsaturated fatty acids (PUFA) content of unenriched inert diet was $10.05 \%$ whereas that of enriched micro diet was $22.3 \%$. PUFA viz. EPA and DHA showed higher levels in enriched diet. Enrichment process increased the PUFA level in Artemia with EPA and DHA in Artemia nauplii ranging from 8.48\% (unenriched Artemia) to $20.41 \%$ (enriched Artemia).

\section{Fry whole body fatty acid profile}

After 60 days experimental trial, the whole body fatty acid composition of T. khudree fry reflected dietary effect and is given in Table 6. Significant $(P<0.05)$ increase in $n-3$ PUFA such as EPA $(20: 3$ $\mathrm{n}-3)$ and DHA (22:6 n-3) was observed in T1, T2 and T3 compared to control due to higher EPA and DHA content in diet after enrichment. Highest EPA content was observed in T3 followed by T1 and T2. DHA content was highest in $\mathrm{T} 3$ followed by $\mathrm{T} 2$ and $\mathrm{T} 1$.

\section{Principal component analysis (PCA)}

Principal component analyses (PCA) of samples with the different fatty acids are plotted in score plot and bi-plot and are presented in Figure 4. Score plot describes change in position of T3 from the initial position whereas $\mathrm{T} 1$ and $\mathrm{T} 2$ fall on the same area indicating similar effect due to dietary treatments. Bi-plot analysis also reveals shift in position and the shift was found to be due to dietary PUFA viz. 18:3 n-3; 22:6 n-3; 20:5 n-3. T3 (unenriched inert diet+enriched Artemia) showed the best performance with highest level of PUFA.

\section{Discussion}

Although live foods are often good sources of nutrition, for many fish species, these traditional food sources have been found to 
Citation: Singh SK, Mishra U, Roy SD, Chadha NK, Venkateshwarlu G (2012) Effect of Feeding Enriched Formulated Diet and Live Feed on Growth, Survival and Fatty Acid Profile of Deccan Mahseer, Tor Khudree (Sykes) First Feeding Fry. J Aquacult Res Dev 3:143 doi:10.4172/21559546.1000143

Page 5 of 6

\begin{tabular}{|c|c|c|c|c|}
\hline Fatty acids & Diet 1 (T0) & Diet 2 (T1) & Diet 3 (T2) & Diet 4 (T3) \\
\hline 12:0 & $0.04 \pm 0.00^{\mathrm{a}}$ & $0.13 \pm 0.01^{\mathrm{a}}$ & $0.21 \pm 0.03^{\mathrm{ab}}$ & $0.36 \pm 0.16^{b}$ \\
\hline 14:0 & $3.31 \pm 0.00^{\mathrm{a}}$ & $5.50 \pm 0.07^{\circ}$ & $3.99 \pm 0.09^{b}$ & $3.28 \pm 0.09^{a}$ \\
\hline 15:0 & $0.73 \pm 0.01^{\mathrm{a}}$ & $0.84 \pm 0.08^{a}$ & $0.97 \pm 0.21^{\mathrm{a}}$ & $0.79 \pm 0.13^{a}$ \\
\hline 16:0 & $0.73 \pm 0.01^{\mathrm{a}}$ & $0.84 \pm 0.08^{\mathrm{a}}$ & $0.97 \pm 0.21^{a}$ & $0.79 \pm 0.13^{\mathrm{a}}$ \\
\hline $16: 1 n-9$ & $6.25 \pm 0.14^{c}$ & $3.47 \pm 0.08^{b}$ & $1.96 \pm 0.05^{a}$ & $2.13 \pm 0.14^{a}$ \\
\hline $16: 1 n-7$ & $0.46 \pm 0.02^{a}$ & $1.08 \pm 0.15^{b}$ & $0.60 \pm 0.06^{a}$ & $1.14 \pm 0.07^{b}$ \\
\hline 17:0 & $1.25 \pm 0.14^{b}$ & $0.67 \pm 0.63^{\mathrm{a}}$ & $0.94 \pm 0.16^{\mathrm{a}}$ & $0.78 \pm 0.05^{\mathrm{a}}$ \\
\hline 18:0 & $12.25 \pm 0.87^{b}$ & $2.86 \pm 0.17^{a}$ & $2.63 \pm 0.18^{a}$ & $3.20 \pm 0.21^{a}$ \\
\hline $18: 1 n-9$ & $16.15 \pm 0.03^{a}$ & $31.77 \pm 0.15^{d}$ & $29.60 \pm 0.13^{c}$ & $28.63 \pm 0.36^{b}$ \\
\hline $18: 1 n-7$ & $2.35 \pm 0.14^{\mathrm{a}}$ & $2.32 \pm 0.20^{\mathrm{a}}$ & $2.94 \pm 0.12^{b}$ & $4.91 \pm 0.32^{c}$ \\
\hline $18: 2 n-6$ & $18.02 \pm 0.29^{c}$ & $10.39 \pm 0.22^{\mathrm{a}}$ & $12.69 \pm 0.30^{b}$ & $10.53 \pm 0.13^{\mathrm{a}}$ \\
\hline $18: 3 n-3$ & $4.35 \pm 0.14^{b}$ & $3.55 \pm 0.26^{a}$ & $4.37 \pm 0.08^{b}$ & $6.97 \pm 0.14^{c}$ \\
\hline 19:0 & $0.14 \pm 0.14$ & ND & ND & $0.18 \pm 0.02$ \\
\hline $20: 0$ & $0.23 \pm 0.02^{\mathrm{a}}$ & $0.61 \pm 0.15^{b}$ & $0.30 \pm 0.01^{a}$ & $0.34 \pm 0.04^{a}$ \\
\hline $20: 1 \mathrm{n}-9$ & $1.70 \pm 0.12^{\mathrm{a}}$ & $3.72 \pm 0.03^{c}$ & $3.96 \pm 0.08^{c}$ & $2.34 \pm 0.07^{b}$ \\
\hline $20: 2 n-9$ & $0.43 \pm 0.01$ & ND & ND & ND \\
\hline $20: 2 n-6$ & $0.11 \pm 0.01^{a}$ & $0.18 \pm 0.02^{b}$ & $0.25 \pm 0.25^{b}$ & $0.26 \pm 0.03^{c}$ \\
\hline $20: 2 n-7$ & $0.12 \pm 0.01^{\mathrm{a}}$ & $0.68 \pm 0.02^{c}$ & $0.47 \pm 0.01^{b}$ & $0.39 \pm 0.08^{b}$ \\
\hline $20: 3 n-9$ & $0.26 \pm 0.01$ & ND & ND & ND \\
\hline $20: 3 n-7$ & $0.75 \pm 0.09^{b}$ & $0.29 \pm 0.03^{\mathrm{a}}$ & $0.47 \pm 0.07^{a}$ & $0.94 \pm 0.05^{b}$ \\
\hline $20: 4$ n-6 (AA) & $1.24 \pm 0.01^{\mathrm{a}}$ & $1.31 \pm 0.00^{\mathrm{ab}}$ & $1.35 \pm 0.07^{\mathrm{ab}}$ & $1.41 \pm 0.00^{\mathrm{b}}$ \\
\hline $20: 3 n-3$ & $1.60 \pm 0.06^{d}$ & $0.73 \pm 0.03^{b}$ & $0.55 \pm 0.02^{\mathrm{a}}$ & $0.93 \pm 0.04^{c}$ \\
\hline $20: 4 n-3$ & $1.31 \pm 0.01^{\mathrm{a}}$ & $0.56 \pm 0.06^{b}$ & $0.47 \pm 0.35^{b}$ & $1.20 \pm 0.01^{a}$ \\
\hline $20: 5$ n-3 (EPA) & $4.01 \pm 0.00^{\mathrm{a}}$ & $4.45 \pm 0.20^{\mathrm{b}}$ & $4.40 \pm 0.01^{b}$ & $6.50 \pm 0.05^{c}$ \\
\hline 22:1 n-9 & $1.30 \pm 0.02^{b}$ & $1.42 \pm 0.09^{b c}$ & $1.55 \pm 0.07^{\circ}$ & $0.28 \pm 0.04^{a}$ \\
\hline $22: 6 n-3(\mathrm{DHA})$ & $3.21 \pm 0.00^{\mathrm{a}}$ & $3.55 \pm 0.02^{b}$ & $4.15 \pm 0.01^{c}$ & $5.40 \pm 0.06^{d}$ \\
\hline
\end{tabular}

Values expressed as mean \pm standard deviation, $n=3$.

Superscripts (a, b, c, d) denotes significant differences among the diets $(P<0.05)$ $\mathrm{ND}=$ not detected.

AA: Arachidonic acid

EPA: Eicosapentaenoic acid

DHA: Docosahexaenoic acid

Table 6: Fatty acid profile of $T$. khudree fry fed with different experimental diets for a 60 days period.

be inadequate to support nutritional requirement. It has been well established that one of the limiting factors in nutrition of early stages of fishes is the level of n-3 HUFA. Hence certain feeds containing HUFAs (especially DHA, 22:6 n-3 and EPA 20:5 n-3) can be valuable as food sources for enrichment. Also, feed ingestion and digestion do not appear to be regulated by total lipid content, but by the lipid source and fatty acid composition [26].

In the present study, EPA/DHA enriched diet (T1, T2 and T3) exerted significant effect $(P<0.05)$ on percentage weight gain of $T$. khudree fry compared to unenriched inert diet (T0). Fry co-fed with enriched Artemia and unenriched inert diet promoted highest percentage weight gain, specific growth rate and average daily growth (Figures 1-3). These may be explained by higher percentage of EPA and DHA accumulated in enriched Artemia and growth promoting effect of these fatty acids. Significantly lower growth in fry fed only inert diet (T0 and T1) signifies that mahseer fry at this stage are unable to metabolise the diet and may be due to partially functional digestive system. Moreover, physical aspects such as particle size, distribution and attractiveness of the formulated diets can affect larval ingestion [26]. According to Cahu and Zambonino [27] the enzyme activity pattern is age-dependent, but can be modulated by the inert diet. Live food given together with a formulated diet is reported to enhance the efficiency of the formulated diet by promoting the assimilation and deposition of dietary nutrients in the larval body [7].

In the present study, low feed intake (data not shown) was observed in groups fed only inert diet which may be due to low palatability of the inert diet as explained by higher FCR. In treatments T2 and T3, better feed consumption when $50 \%$ of the live prey are substituted by inert diet provides future avenues for formulating low feed cost for this species. EPA and DHA (HUFA) play a major role growth process during early stages of this fishes. In the present experiment, EPA/DHA levels were comparatively higher in enriched Artemia than present in the inert diets. This result may explain a major beneficial role of live food as an effective carrier vehicle for EPA/DHA during early stages. Fry percent survival was significant after $45^{\text {th }}$ day of experimental trial (Figure 3). Fry fed completely on inert diet exhibited low survival rate compared to fry co-fed with both inert and live feed. This may be due to higher supplementation of dietary lipid in formulated diet which would impact the water quality as seen in our study. Oil films were observed in tanks which would choke the gills of developing fry and increases stressful conditions. Mahseer fry co-fed on inert diet and enriched live feed had the highest survival rate and this could be explained by better assimilation of dietary EPA/DHA through live food enrichment. It has been established that high levels of (n-3) HUFA in the live feed can improve survival of fish larvae in a number of species [28]. The higher survival percentage may be due to the enhancement of ability of fry to withstand stressful environment by feeding on HUFA enriched Artemia nauplii.

The present experiment was also designed to evaluate HUFA retention capacity of cold water fish species, T. khudree fry after experimental feeding with both live feed and inert diet. As the early life stages of fishes have limited capacity to elongate and desaturate 18-carbon PUFA, freshwater species require supplemented PUFA in their diet. In the present study, dietary lipid levels in both inert and
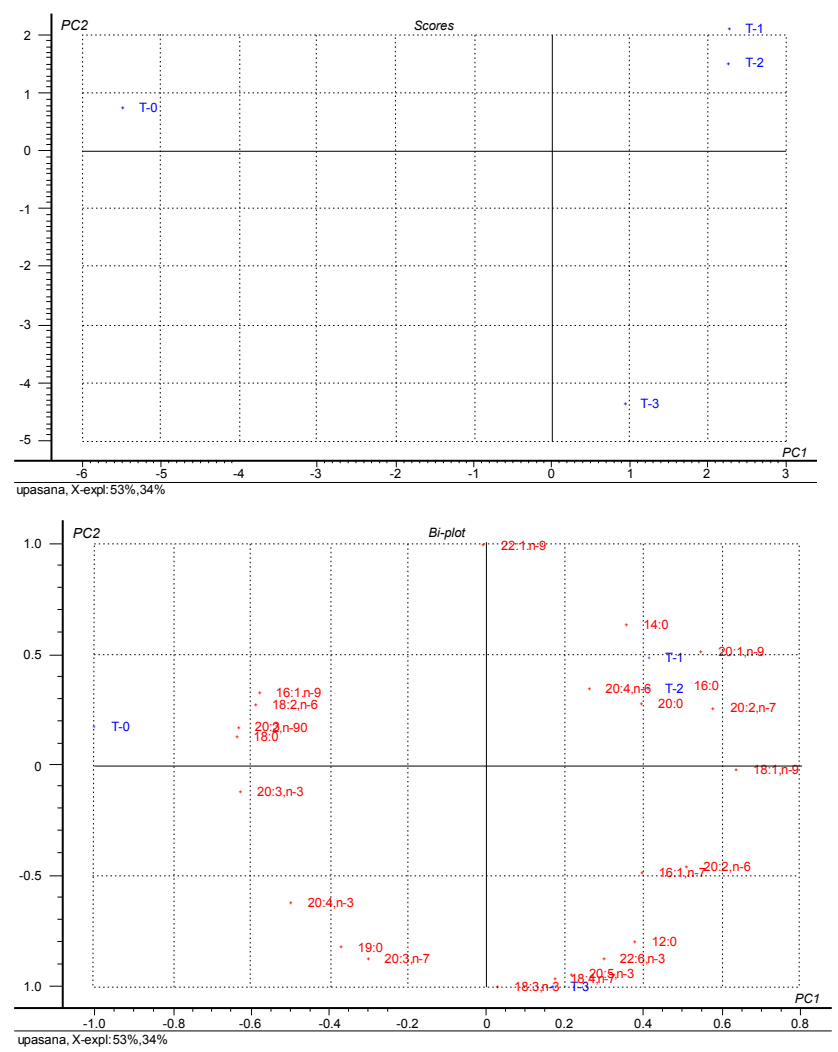

Figure 4: Score plot and bi plot showing the difference in the fatty acid profiles of $T$. khudree fry fed with different experimental diets. 
Citation: Singh SK, Mishra U, Roy SD, Chadha NK, Venkateshwarlu G (2012) Effect of Feeding Enriched Formulated Diet and Live Feed on Growth, Survival and Fatty Acid Profile of Deccan Mahseer, Tor Khudree (Sykes) First Feeding Fry. J Aquacult Res Dev 3:143 doi:10.4172/21559546.1000143

live feed exerted significant effect on some class of fatty acid in the fish. Highest EPA level was observed in fry fed combination of enriched Artemia and unenriched diet (T3). This observation suggests that beneficial EPA is transformed more efficiently into tissue when live feed are enriched with EPA rich sources. Fry fed combination of unenriched Artemia and enriched Artemia had less EPA in tissue compared to T3. Dietary DHA levels had similar effect on the tissue fatty acid level with lowest value observed in control (T0) and highest value in T3. From the above results it can be concluded that enrichment process using live feed as vehicle for transport of essential fatty acids serves the purpose of maintaining the fatty acid requirement of the early young stages of T. khudree fry and subsequently higher accumulation in fish would provide avenues for fish products as source of these fatty acids.

Principal components analysis reveals that irrespective of the diet, lipid fractions shows distinct fatty acid patterns. The fish fed with PUFA enriched diet and enriched Artemia for 60 days were different from initial position based on fatty acid composition. PUFA, n-3 PUFA, MUFA, 18:2 n-6, 18:1 n-9 and 22:6 n-3 were found to be responsible for causing the differences among the samples and T3 showed the best performance with high level of PUFA in this experiment. This was supported by Karanth et al. [29] where the PCA shows the differences in the muscle fatty acid profiles of fish fed with different dietary groups enriched with PUFA which were found to be responsible for causing the differences among the samples.

\section{Conclusion}

Result from the present study reveals that nutritional quality of Artemia can be improved by enriching with EPA and DHA rich sources such as cod liver oil which is easily available in market. EPA and DHA being essential for early life stages can improve growth and survival as observed in our study. Further, co-feeding early stages of cold water species with enriched live feed in combination with inert diet can further reduce the live feed cost. Thus this study provides an opportunity for growth enhancement and better survival in cold water species, Tor khudree through nutritional manipulation so that optimum sized fingerlings can be produced to make its culture a viable commercial activity and protect the species from extinction in the wild.

\section{Acknowledgements}

The authors are thankful to Dr. W.S. Lakra, Director, Central Institute of Fisheries Education (CIFE), Mumbai and Indian Council of Agricultural Research, New Delhi, India for supporting the project and providing the necessary assistance related to the study. We are also grateful to Head of Division, Post Harvest Technology, CIFE for the facilities provided during laboratory analysis.

\section{References}

1. Ogale SN (2002) Mahseer breeding and conservation and possibilities of commercial culture. The Indian experience. FAO Fisheries Technical Paper 431: 193-212.

2. Das P, Joshi KD (1994) Mahseer conservation: present and future. In: Nautiyal P (ed.) Mahseer: The Game Fish: D3-D9. Rachna, Srinagar, India.

3. Rosenlund G, Stoss J, Talbot C (1997) Co-feeding marine fish larvae with inert and live diets. Aquaculture 155: 183-191.

4. Engrola S, Conceição LEC, Dias L, Pereira R, Ribeiro L, Dinis MT, et al. (2007) Improving weaning strategies for Senegalese sole: effects of body weight and digestive capacity. Aquac Res 38: 696-707.

5. Evjemo JO, Coutteau P, Olsen $Y$, Sorgeloos $P$ (1997) The stability of docosahexaenoic acid in two Artemia species following enrichment and subsequent starvation. Aquaculture 155: 135-148.

6. Rønnestad I, Thorsen A, Finn RN (1999) Fish larval nutrition: a review of recent advances in the roles of amino acids. Aquaculture 177: 201-216.

7. Kolkovski S, Tandler A, Izquierdo MS (1997) Effects of live food and dietary digestive enzymes on the efficiency of microdiets for seabass (Dicentrarchus labrax) larvae. Aquaculture 148: 313-322.

8. Koven W, Barr Y, Lutzky S, Ben-Atia I, Weiss R, et al. (2001) The effect of dietary arachidonic acid( $20: 4 \mathrm{n}-6)$ on growth, survival and resistance to handling stress in gilthead seabream (Sparus aurata) larvae. Aquaculture 193: 107-122.

9. Bell JG, McEvoy LA, Estevez A, Shields RJ, Sargent JR (2003) Optimising lipid nutrition in first-feeding flatfish larvae. Aquaculture 227: 211-220.

10. Webster C D, Lim CE (2002) Nutrient requirements and feeding of finfish for aquaculture. CABI Publishing, New York.

11. Tidwell JH, Coyle, S, Bright, LA (2007) Effects of Different Types of Dietary Lipids on Growth and Fatty Acid Composition of Largemouth Bass. North American Journal of Aquaculture. 69: 257-264.

12. Lovell RT (1991) Nutrition of aquaculture species. J Anim Sci 69: 4193-4200.

13. Olsen Al, Olsen Y, Attramadal Y, Christie K, Birkbeck TH, et al. (2000) Effects of short term feeding of microalgae on the bacterial flora associated with juvenile Artemia franciscana. Aquaculture 190: 11-25.

14. Takeuchi T, Toyota M, Satoh S, Watanabe T (1990) Requirement of juvenile red seabream Pagrus major for eicosapentaenoic and docosahexaenoic acids. Nippon Suisan Gakkaishi 56: 1263-126.

15. Dhert P, Felix MG, Ryckeghem KV, Geurden I, Thysen F, et al. (1999) Cofeeding of phospholipids to turbot Scophthalmus maximus L. larvae as a tool to reduce live food consumption. Aquacult Nutri 5: 237-245.

16. Chepkirui-Boit V, Ngugi CC, Bowman J, Oyoo-Okoth E, Rasowo J, et al. (2011) Growth performance, survival, feed utilization and nutrient utilization of African catfish (Clarias gariepinus) larvae co-fed Artemia and a micro-diet containing freshwater atyid shrimp (Caridina nilotica) during weaning. Aquacul Nutri 17 e82-e89.

17. Chang Q, Liang MQ, Wang JL, Chen SQ, Zhang XM, et al. (2006) Influence of larval co-feeding with live and inert diets on weaning the tongue sole Cynoglossus semilaevis. Aquacul Nutri 12: 135-139.

18. Curnow J, King J, Partridge G, Kolkovski S (2006) Effects of two commercial microdiets on growth and survival of barramundi (Lates calcarifer Bloch) larvae within various early weaning protocols. Aquacul Nutri 12: 247-255.

19. Hamre K, Naess T, Espe M, Holm JC, Lie O (2001) A formulated diet for Atlantic halibut (Hippoglossus hippoglossus, L.) larvae. Aquacul Nutri 7: 123-132.

20. Khemis IB, Audet C, Fournier R, Noüe JDL (2003) Early weaning of winter flounder (Pseudopleuronectes americanus Walbaum) larvae on a commercia microencapsulated diet. Aquacult Res 34: 445-452.

21. Blair T, Castell J, Neil S, D’Abramo L, Cahu C, et al. (2003) Evaluation of microdiets versus live feeds on growth, survival and fatty acid composition of larval haddock (Melanogrammus aeglefinus). Aquaculture 225: 451-461.

22. Sangma KON, Basavaraj N (2012) Comparative growth and survival of hatchery produced and wildfingerlings of Deccan Mahseer, Tor khudree (Sykes). Indian J Fish 59: 89-93.

23. Sorgeloos P, Lavens P, Leger P, Tackaert W, Versichele D (1986) Manual on the cultivation and use of Artemia in aquaculture. (Ed), United Nations Organization for Agriculture and Nutrition Aquila Project Doc 10: 301.

24. Folch J, Lees N, Sloane-Stanley GH (1957) A simple method for the isolation and purification of total lipides from animal tissues. J Biol Chem 226: 497-509.

25. AOAC (1995) Official Methods of Analysis of Official Analytical Chemists, Vol. 1, (16thedn), (ed. by P.A. Cunniff) AOAC International, Arlington, VA, USA.

26. Baskerville-Bridges, Kling (2000) Development and evaluation of microparticulate diets for early weaning of Atlantic cod Gadus morhua larvae. Aquacult Nutri 6: 171-182.

27. Cahu C, Zambonino Infante J (2001) Substitution of live food by formulated diets in marine fish larvae. Aquaculture 200: 161-180.

28. Izquierdo MS, Watanabe T, Takeuchi T, Arakawa T, Kitajima (1989) Requirement of larval seabream Pagrus major for essential fatty acids. Nion Suisan Gakkaishi 55: 859-867.

29. Karanth S, Sharma P, Pal AK, Venkateshwarlu G (2009) Effect of different vegetable oils on growth and fatty acid profile of Rohu (Labeo rohita, Hamilton): Evaluation of a return fish oil diet to restore human cardio-protective fatty acids. Asian-Australian Journal of Animal Science 22: 565-575. 